\title{
An «instructional» perspective on entrepreneurship education - focusing on the development of team competencies
}

\author{
Susanne Weber, Sabine Funke
}

Ludwig-Maximilians-Universität, Munich*

\begin{abstract}
Successful entrepreneurs are identified as the main driving force for economy. Therefore, in many countries various programs evoking and developing entrepreneurial activities are set up by governments with huge financial support. As current evaluations come up with different results of their effectiveness a meta-study suggests to use variables of outcomes of human capital investments (processes of learning, knowledge, skills) instead of variables of investments of human capital (education, experience) for monitoring and evaluating output and outcomes of entrepreneurial courses and programs. Within this study we pick up these challenges by firstly analyzing strengths and weaknesses of current entrepreneurship programs using the «curriculum-instruction-assessment-triad» as a heuristic frame. Secondly, we introduce a theorybased instruction approach for entrepreneurship education and present thirdly a first glance of assessment. The study is run within a compulsory business course for bachelor students. The results show by a pre-post-experimentalcontrol-group design that the exemplarily focused curricular goal «team competencies» could be developed.
\end{abstract}

Keywords: curriculum-instruction-assessment-triad, team competencies, entrepreneurship education, competence measurement, IRT

\section{Introduction}

Successful entrepreneurs are identified as the main driving force for economy (Schumpeter, 1911; Klandt, 2006; Reynolds, 2007). Therefore, Germany started in 1998 with a country-wide entrepreneurial development program EXIST of 80 million Euro (EXIST I-III). The aim was to improve the entrepreneurial climate at universities and to rise the amount of technology and knowledge driven spin-offs (BMWI, 2006; Egeln, Dinges, Knie et al., 2010) by means of public relations, on-

\footnotetext{
* Susanne Weber, Institute for Human Resource Education and Management Ludwig-MaximiliansUniversität München, LMU, Germany; susanne.weber@bwl.lmu.de

Sabine Funke, Institute for Human Resource Education and Management, Ludwig-Maximilians-Universität München, LMU, Germany; funke@bwl.lmu.de
} 
spot-assistance, canvassing of potential entrepreneurs, business planning and idea competitions, teaching entrepreneurial knowledge, entrepreneurial spirits as well as entrepreneurial activities (Kulicke, 2006). By this, lot of universities implemented entrepreneurial modules to promote «key competencies» compulsorily within their bachelor programs (Klandt, 2004b; Koch, 2003; Schmude, Heumann \& Wagner, 2009; Uebelacker, 2005; Kuratko, 2005). First overarching evaluation results run by the Centre for European Economic Research (ZEW) from an economical point of view show that these EXIST-Programs did not have a significant impact on start-upactivities of scientists and academics (Egeln et al., 2010). Correspondingly, Unger, Rauch, Frese and Rosenbusch (2011) showed by their meta-analytical review that entrepreneurial success is much more related to outcomes of human capital investments (processes of learning, knowledge, skills) than to investments of human capital (education, experience). Thus, the question from the perspective of human resource education and management - focusing on the outcomes of human capital investments - arises how to design, implement and evaluate efficient and effective entrepreneurship courses. For these considerations we use the research- and evidencebased «curriculum-instruction-assessment triad» of Pellegrino (2010) and Wilson, Bejar, Scalise et al. (2010) as a heuristic framework (cf. also Achtenhagen, in this volume): (a) Thus, we highlight by this triad the strengths and weaknesses as well as the interrelationship of current curricula, instructional approaches and assessment procedures in entrepreneurship education and (b) suggest a corresponding instructional entrepreneurship design. The analyses of current entrepreneurship courses show that the curricular goals mostly stay diffuse and global: they often are labeled by nouns like «collaboration», «teamwork», «information on market», «price calculation», «financial plan» etc. rather than being structured and operationalized with regard to concepts like knowledge, skills or attitudes or being linked to specific entrepreneurial situational challenges to be mastered. Most entrepreneurship programs and courses focus according to Ajzen's theory of planned behavior (1987) on evoking and fostering «the entrepreneurial intention» (often measured by one item: «My occupational goal is to become an entrepreneur.») and related impact factors as their main (curricular) goal (Kolvereid \& Isaksen, 2006; Liñán \& Chen, 2009; Engle, Dimitriadi, Gavidia et al., 2010; Lee, Wong, Foo \& Leung, 2011). As main impact factors on «entrepreneurial intention» are assumed «personal attractiveness» or «perceived behavioral control» of being able to successfully conduct or realize entrepreneurial activities (Liñán, Moriano \& Zarnowska, 2008). According to the meta-analysis of Armitage \& Conner (2001) Ajzen's construct of «intention» can be seen as the best predictor for later real entrepreneurial acting (with about $27 \%$ of explained variance). With regard to realizations of start-ups which are done on average five years after finishing university (Achleitner, Klandt, Koch et al., 2006, p. 221; Fueglistaller, Klandt, Halter et al., 2009, p. 14), the construct of «intention» is seen as a good approximation for predicting later founding. An empirically based decision which abilities resp. facets of abilities have to be focused on within an entrepreneurial course cannot be made at the moment (cf. Fayolle, 2008; Izquierdo \& 
Deschoolmeester, 2010). An agreement seems to exist about the fact that knowledge, skills and attitudes with regard to so-called hard-skills (like knowledge of central elements of a business plan or knowledge of how to write a financial plan) as well as to soft-skills (like knowledge of how to organize the tasks within the entrepreneurial team, presenting the business plan to a possible venture capitalist) should be involved and are necessary. With regard to the level of these abilities to be achieved within entrepreneurial courses, most progams - especially at the level of universities - differentiate between so-called courses of sensibilization/awareness (low level) and courses of qualification (high level; including the writing of business plans) (Liñán, Moriano \& Zarnowska, 2008, Liñán, 2007; Liñán, 2004). The focus on the «sense of failure/sense of success»-approach might lead to new ways of differentiation (cf. Oser \& Volery, in this volume).

With regard to instruction - the question of how to teach and learn entrepreneurial behavior is hardly be answered as the curricular goals are still diffuse and summed up by broad labels. Thus, most authors in entrepreneurship education recommend action-based or experiential learning methods like firm simulations, firm visits/explorations, writing business plans etc. instead of more passive reception-oriented methods like traditional lectures, readings etc. (Müller, 2011; Uebelacker, 2005; Walter \& Walter, 2008). The empirical study of Sherman, Sebora \& Digman (2008) shows that experiential learning activities are rated as having a higher impact on learners' intention for starting a business than non-experiential learning activities as e.g., reading, listening and watching. Analyses of Müller (2011) show that didactical elements implemented into entrepreneurship courses are often only chosen for plausibility reasons and/or by chance. Instruction in entrepreneurial courses is insufficiently related to the state-of-the-art of teaching-learning-theory. As a consequence we need more precision of curricular goals, information about their nature (knowledge, skills, attitudes), how they can be taught and learned as well as a solid empirical and theoretical foundation of instruction which corresponds to the complexity and multitude of curricular goals. For the fields of business and economic education and human resource education there exist an extended source of empirical subjectdidactical research resp. pedagogical content knowledge (Shulman, 1986; Achtenhagen \& Pätzold, 2011). For the field of entrepreneurship education and business planning a huge deficit of subject-didactic research is still given.

Assessment of learning and developmental processes within entrepreneurial programs in higher education is run at different levels and with regard to different manifest and latent variables: with regard to manifest output measures evaluations are focusing on «the number of created new businesses and jobs, patents, technology licenses» (university-wide output measures) (see e.g. the evaluation of EXIST, Egeln et al., 2010), «the enrolments across university: e.g. participation of departments, students, faculty members» (reach of program); with regard to latent output measures evaluations are focusing mainly on the concept of entrepreneurial intention, attitudes and beliefs held towards entrepreneurship and self-employment and corresponding antecedents like in Ajzen's model of planned behavior (Volkmann, Wilson, 
Mariotti et al., 2009; Ajzen, 1991). The use of Ajzen's model is also dominant because its dependent output variable is not biased by «survival» aspects and/or expost rationalizations of the learner (Walter \& Walter, 2008). A lot of studies show positive effects of entrepreneurial programs on the latent constructs of «perceived personal attractiveness» as well as «perceived behavioral control» towards entrepreneurship and self-employment (e.g. Peterman \& Kennedy, 2003; Tkachev \& Kolvereid, 1999), but there are also contradictory study results (e.g. Mansio, 1997; Oosterbeek, van Praag \& Ijsselstein, 2010). Fayolle and Gailly (2009) suggest taking additional context variables into account. These problems and inconsistent results of assessment might be interpreted with regard to several didactically and methodologically driven shortcomings. They do not meet the requirements of the heuristic components of the curriculum-instruction-assessment triad: (a) they stick with unclear curricular goals which are not sufficiently related to adequate instructional means and necessary corresponding assessments; (b) methodological shortcomings are related to a biased sampling related to self-selection, use of weak designs, restricted data explorations, sticking with the sample means for learners' entrepreneurial intention (Lüthje \& Franke, 2003; Peterman \& Kennedy, 2003; Pittaway \& Cope, 2007; Souitaris, Zerbinat \& Al-Laham, 2007) - if there any evaluation is run (Henry, Hill \& Leitch, 2003; Kailer, 2007). New studies show segmentation effects on entrepreneurial programs: that means that the program might support a group of learners in fostering their intention to found a start-up and another group of learners making up explicitly contradictory career decisions (von Graevenitz, Harhoff \& Weber, 2010) - an aspect which is not taken into account up to now very often.

Within this article we pick up these challenges and shortcomings by departing from solidly operationalized and precisely defined curricular goals, designing and implementing a corresponding research-based instruction and by evaluating the intervention with assessing hard and soft skills - here restricted to team competencies (for the competence of «networking» see Weber \& Starke, 2010; Starke, 2011). All three steps are thoroughly linked to each other like in the curriculum-instructionassessment triad.

\section{Designing an instruction for fostering the entrepreneurial competence facet of teamwork}

As an instruction can only be judged with regard to its set goals and whether it strikes the learners we link the instruction to corresponding curricular goals and assessment.

\subsection{Fixing the curriculum components}

For identifying, selecting and legitimating the curricular goals we ran an extended research on entrepreneurial literature and practical suggestions of business planning (cf. Klandt, 2003, p. 101; Lang-von Wins, Leiner, von Rosenstiel et al., 2002; Arndt, 
2006; evobis, 2011). The findings can be categorized as: (a) workplace/job-oriented challenges like: information gathering, decision making under uncertain conditions, handling tools for running analyses; (b) worker-oriented abilities like: achievement orientation, knowledge and skills for creating a business plan, level of experience in a branch and (c) phase-depending entrepreneurial activities like e.g. detecting founding opportunities in the pre-founding phase, realizing administrative and organizational structures in the founding phase, acquiring new and holding first/old customers in the post-founding phase (cf. Klandt, 2003, 2004a). It turned out that beside so-called hard skills like knowledge of the business branch, planning and writing a business plan or calculating the new product price also a lot of so-called soft skills like knowledge of how teams work, skills to coordinate teamwork and networking for gathering resources as well as presenting to and convincing the venture capitalist are decisive and indispensable entrepreneurial abilities - especially within the first phase of entrepreneurship education.

It has become apparent from our analyses that team competencies are indispensable competencies for mastering start up-challenges over different phases (Brüderl, Preisendörfer \& Ziegler, 2009; Walter \& Walter, 2008; Volery \& Shaper, 2007; De Carolis, Litzky, \& Eddleston, 2009); studies in higher education showed that students feel at the end of their study time not sufficiently educated with regard to the affordances in work teams (Briedies, 2007, p. 64). We, therefore, focus on team competencies as a decisive curricular goal of our entrepreneurship course. On the basis of an extensive literature review on teamwork and team competencies (cf. Decuyper, Dochy \& van den Bossche, 2010; Figl, 2010a, b; Mathieu, Maynard, Rapp et al., 2008), we operationalized this curricular learning goal according to (a) the team competence model (KSA) of Stevens and Campion (1994; 1999); to (b) Cannon-Bowers' approach identifying various knowledge, skills and attitudes associated with effective team performance (Cannon-Bowers, Tannenbaum, Salas et al., 1995, p. 340); to (c) Baker's model of team competencies within the «Adult Literacy and Life Skills Survey» (ALL) (Baker et al., 2005) and (d) Weinert's (2002) definition of competencies as it is used in current national and international research on modeling and measuring competencies (cf. Klieme \& Hartig, 2008, p. 16, in the context of PISA; Baker, Horvath, Campion et al., 2005 in the context of the ALL survey; Lehmann \& Seeber, 2007; Seeber, 2008; Achtenhagen \& Winther, 2009; Winther, 2010; Seeber \& Nickolaus, 2010; Nickolaus, 2011; Weber \& Hofmuth, 2011,2012 , in the context of business and human resource education and management). On this basis we define team competencies as context specific individual knowledge-, skill- and attitude-oriented dispositions, which are functionally linked to domain-specific situations of teamwork with their implied challenges/affordances. Figure 1 shows our model of team competencies. 
Figure 1: Theoretical model of team competencies

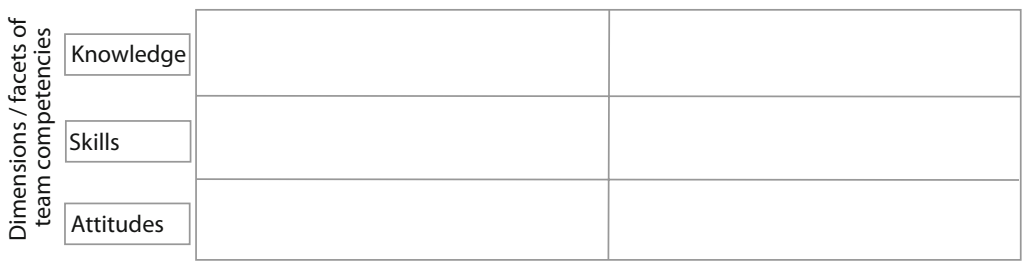

Situations of team work

\begin{tabular}{|c|c|c|c|c|c|c|}
\hline \multicolumn{4}{|c|}{ Task management } & \multicolumn{3}{|c|}{ Relation management } \\
\hline $\begin{array}{c}\text { Goal } \\
\text { setting }\end{array}$ & Planning & Monitoring & $\begin{array}{c}\text { Task } \\
\text { coordination }\end{array}$ & $\begin{array}{l}\text { Conflict } \\
\text { resolution }\end{array}$ & Collaboration & Communication \\
\hline 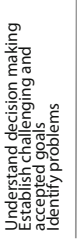 & 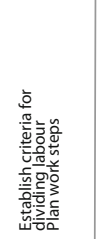 & 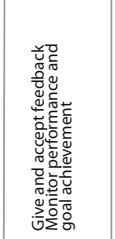 & 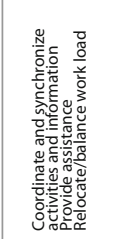 & 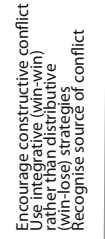 & 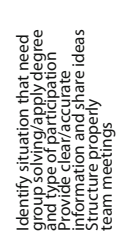 & 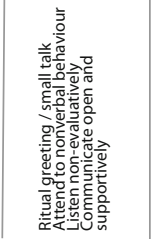 \\
\hline
\end{tabular}

Source: own creation

(I) The domain-specific situations of teamwork and their challenges are specified by the above mentioned team research results as (a) task-management including challenges/tasks of goal setting, planning, monitoring and task coordination and (b) relation management including challenges/ tasks of creating and holding good work relationships within collaborative problem solving, valuable/mindful communication and conflict resolution. On the practical level we got information about the distribution of team situations to be mastered in entrepreneurship courses by analyzing protocols written by students in the same course one year before during a coaching and reflection phase which we categorized according to the categories given by the research literature.

By this qualitative ex-post content analysis we wanted to get insight into typical teamwork processes and problems students have to tackle with. We used this nonreactive measure to avoid social desirableness (cf., Ballstaedt, 1982). We got protocols of 285 students. That covers $66,3 \%$ of the whole course. Within two reflection phases (conducted in the 3rd and 9th week of the semester run by the teaching assistant and tutor) the students were asked by their coaches e.g. "What can I do better to solve the team's task?» or «What can I personally do better for improving the team interactions?»-By this we got 1102 responses which were analyzed according to the structured, deductive content analysis of Mayring (2002, p. 115). Each response was categorized with regard to the previously defined theoretical model of team competencies (see Table 1). The results give valuable hints for the organization of teamwork under the auspices of promoting team competencies. 
Table 1: Relevant team situations within the entrepreneurial education course «START with business planning» in the winter semester 2009/10

\begin{tabular}{cccc|ccc}
\hline \multicolumn{3}{c}{ Task management } & & \multicolumn{3}{c}{ Relation management } \\
Goal setting & Planning & Monitoring & $\begin{array}{c}\text { Task } \\
\text { coordination }\end{array}$ & $\begin{array}{c}\text { Conflict } \\
\text { resolution }\end{array}$ & $\begin{array}{c}\text { Collaborative } \\
\text { problem } \\
\text { solving }\end{array}$ & $\begin{array}{c}\text { Communi- } \\
\text { cation }\end{array}$ \\
\hline $1,4 \%$ & $6,2 \%$ & $3,5 \%$ & $13,2 \%$ & $3,1 \%$ & $41,6 \%$ & $31,0 \%$ \\
$\mathrm{~N}=1102(100 \%)$ & $24,3 \%$ & & & $75,7 \%$ & \\
\hline
\end{tabular}

Source: own data

(II) Necessary individual facets of competencies and levels for mastering these challenges are related to Knowledge (including e.g. knowledge on key terms, disturbance factors [declarative], explaining why a team situation does not work [procedural] and knowing solution strategies and predicting main and side effects [strategic]) (Anderson \& Krathwohl, 2001; Marzano \& Kendall, 2007) - corresponding to a «scholarly academic» curricular approach (Schiro, 2008); Skills (including e.g. perceiving good and bad behavior in teamwork situations, linking behavior and problems of teamwork to theoretical concepts and technical terms, creating alternative teamwork behavior or suggestions for particular team situations) (Shavelson, 2010; Nickolaus, 2011) - corresponding to a «social efficiency» curricular approach (Schiro, 2008); and Attitudes (including e.g. convictions that teams are important in work life in these days, beliefs that teams enhance own performance, intention to work in teams) (Baker et al., 2005) - corresponding to the «learner centered» and «social reconstruction» curricular approaches (Schiro, 2008).

For our instruction-component this means that we have to design learning situations in which the learners are faced with relevant and critical team situations (especially those identified by our pre-analysis, Table 1) which they have to master in a competent way by using their resources of team knowledge, team skills and team attitudes. The instruction including teachers, coaches, material etc. has to overtake a supportive and evoking role.

\subsection{Instructional decisions}

From diverse summarizing studies on teaching and learning we know how people learn and which teaching behavior evokes efficient learning processes: especially instructional activities that take the learners' motivation and interests into account and enable participation possibilities to act and to make experiences of own behavior as well as by exploration (learner centered); activities that support the development of content-related mental models (knowledge centered); activities of formative and summative feedback and assessment (assessment centered); and activities making links between the classroom and the local society for developing visions and changing reality (community centered) (cf. the narrative review of CTGV, 1997; Brans- 
ford, Brown \& Cocking, 2000). The meta-analysis of Seidel \& Shavelson (2007) shows the importance of domain-specific activities, social experiences, organization of learning, regulation and monitoring, time for learning, goal setting and orientation, fostering learning processes, motivation and cognition.

From curriculum theory we know that discipline-oriented mental models (knowledge) are best taught by systematic presentations and expert dialogues mostly realized via lectures and tutorials on the university level; skills are best taught via actionand problem-based projects where students can probe and explore their behavioral strategies supported by programmed instruction, by offering supportive learning material like scripted protocols, worked out examples, rules of thumb etc.; attitudes can be developed via appropriate experiences made in open learning environments but also by social critical reflection via engagement and participation in real contexts (cf. Schiro, 2008).

From literature on teamwork effectiveness we know that the organizational and situational context (like reward systems, level of stress, competition, environmental uncertainty etc.) influences the quality of teamwork. For the input level research shows that «task characteristics» are crucial for effective team processes; tasks and problems initiating team processes should have a certain complexity, the «work structure» has to enable team work with regard to aspects like work assignments, team norms, communication structure; «team characteristics « like e.g. group composition or power distribution and «individual characteristics» like domain-related prior-knowledge, skills and attitudes, motivation/interest on the task, personality traits etc. support and/or hinder efficient and effective teamwork. On the process level: the way of decision making, problem solving, coordination, communication, conflict resolution etc. foster or hinder good teamwork. And there are various possibilities to judge a teamwork output (e.g. by team changes [incl. new norms, communication patterns], team performance [e.g. quality, quantity, time] or individual changes [like task and team-based KSAs, motivation/interest etc.]). All can be promoted by feedback and special interventions (cf. especially the model of Tannenbaum, Beard \& Salas, 1992).

The didactical approach «Understanding by design» gives an extended guidance for designing efficient and effective instruction (Wiggins \& McTighe, 2005).

The following paragraph refers to the course «START with business planning» which is compulsory in the third semester of the bachelors' program in Business administration at Ludwig-Maximilians University (LMU) Munich. Responsible for the conception and realization of the course are the Institute for Innovation Research, Technology Management and Entrepreneurship (INNO-tec) (Prof. Harhoff, Ph.D.) and of Human Resource Education and Management (Prof. Dr. Weber) as well as the Center for Entrepreneurship at the LMU Munich. Figure 2 gives an overview about our instructional activities which are classified by (A)-(F). 
Figure 2: Overview on the course «START with business planning»

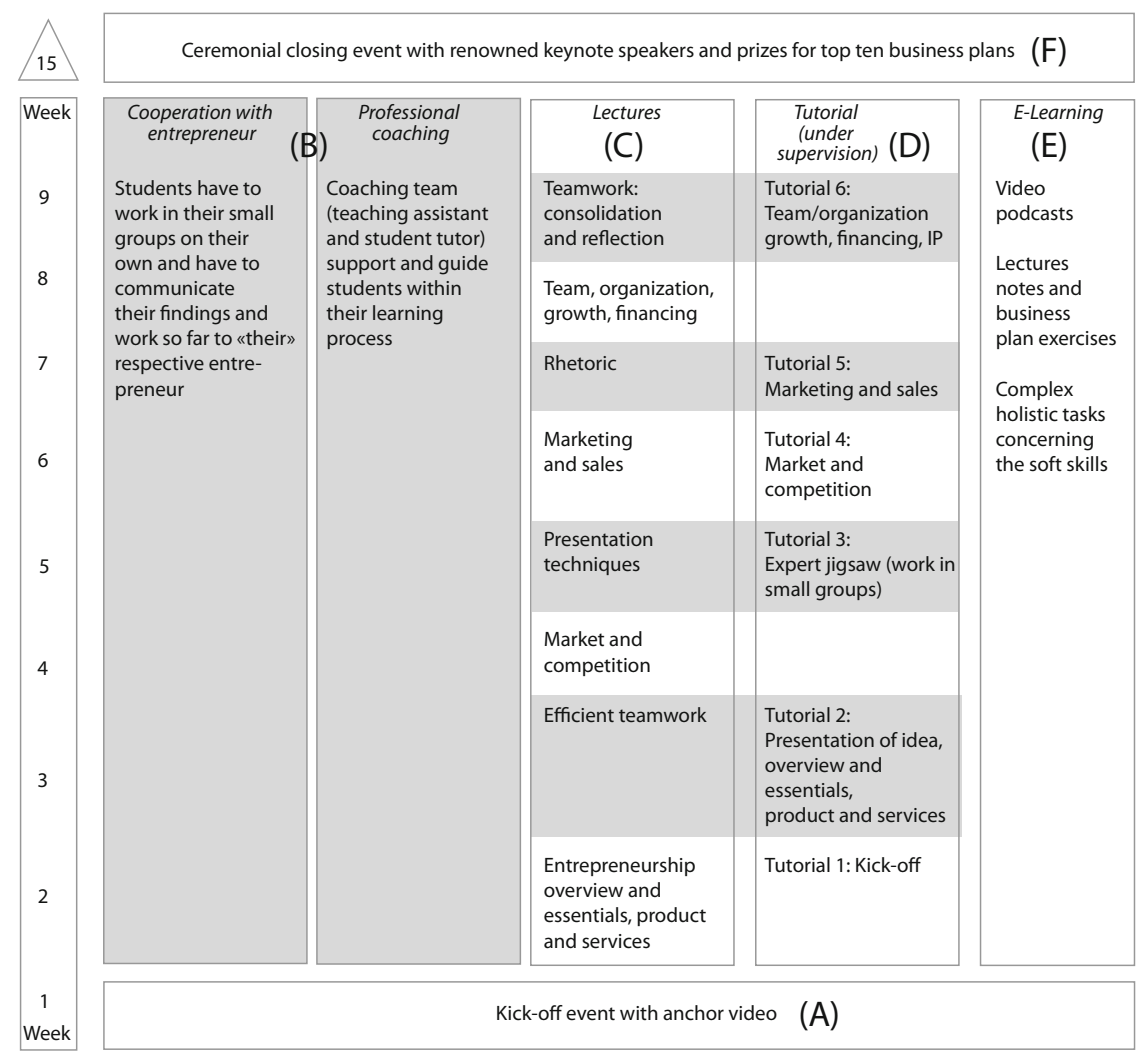

Source: own creation

(A) We started our entrepreneurship course «START with business planning» by means of an anchor video of about twenty minutes: in the broad sense of Ausubel's concept of an «advance organizer» (1960) to introduce into the course concept, to foreshadow the whole course including the set goals, tasks and content to be tackled, to support possibilities and a broad time structure, to give an orientation and to build adequate expectations, to present structure and sequences of a business planning process, to give hints on «how to start», to highlight possible upcoming problems, to re-link single tasks to the overarching problem, to monitor the work processes and, overall, to motivate. By this instructional means we intend to activate students' prior knowledge and to link it with new topics developing deep knowledge and understanding, but also to introduce procedures and rules of thumb for getting started as well as to motivate the students (cf. CTGV, 1997; Walberg \& Paik, 2000, p. 13). The effectiveness of such an «advance organizer» concept is shown by many studies (cf. Mayer, 2008, pp. 377-387). The meta-analysis of Fraser,Walberg, Welch et al. 
(1987) shows a very high effect-size of $.75^{1}$. As one example of larger recent studies the «anchored instruction» approach of the CTGV made efficiently and effectively use of this concept (CTGV, 1997; Woolfolk, 2008, p. 430).

(B) For working on authentic domain-specific tasks we implemented a problembased learning block where the learners have to collaborate with a real entrepreneur and to write for him/her a real business plan. We used here the problem-based learning approach (PBL). Following this tradition learning occurs by making practical experiences while coping with complex real world problems (where the learners have to formulate problems and goals, generate hypotheses about possible solutions, prove hypotheses, detect knowledge gaps, regulate learning processes by themselves, monitor processes and goal achievement). By this, students become active learners and feel responsible for their own learning processes. Teachers and coaches support learners' self-organized learning processes and help them to develop learning strategies, to reflect, and to construct knowledge by balancing the distribution of cognitive load, initiating debates, using questioning strategies, encouraging justifications, focusing on attention by scaffolding and fading, developing shared knowledge and supporting the learners with tools and materials (flip charts, structured protocols, hints for cooperation, reciprocal teaching etc.). Furthermore, learning processes are being monitored and evaluated by formative and summative assessment as well as personal feedback is provided (Hmelo-Silver, 2004, pp. 236, 238; Dochy, Segers, van den Bossche et al., 2003, p. 535). During these problem-based learning processes the whole course of 430 students gets divided by chance into small working teams of about four to five students who get coached by a teaching assistant and a student tutor. Always two teams are working on one start-up idea-competing with all other teams for the best business plan. This project runs over a whole semester. By this treatment we offer the learners a supporting environment for social experience and participation, for experiencing consequences of own behavior as well as autonomy to develop and to probe one's own knowledge and skills, e.g. to establish specific challenging task- and team-oriented goals accepted by the whole team, to be able to recognize sources of team conflict and to implement preventing and solving strategies, to properly structure team meetings, but also the opportunity to experience the additional values and processes of teamwork, to experience and to explore the real life of an entrepreneur by visiting his/her firm, meeting start-up partners, interviewing stakeholders etc. for own career decisions, personal growth and acculturating into the entrepreneurs' world by taking up the «entrepreneurial spirit» etc. Furthermore, under a social reconstruction perspective the students help the entrepreneur to reflect the start-up idea and to rise the opportunity for getting venture capital and by this a life perspective (Figure 2). Lots of research results demonstrate the efficiency and effectivity of this PBL-method, especially with regard to developing flexible knowledge (CTGV, 1997; Hmelo-Silver, 2004, p. 252) as well as problem-

1 Effect size (ES): here difference between means of the experimental and control groups divided by the standard deviation of the control group; see Glass, McGaw \& Smith, 1991; cited in Frey \& Frey-Eiling, 1993, chap. 1, p. 7). 
solving and transfer strategies (Hmelo, 1998; Hmelo, Gotterer \& Bransford, 1997). This is especially the case with gifted and more advanced students (e.g. Duek, 2000). With regard to a comparison of PBL to conventional classroom especially the metaanalyses of Dochy, Segers, van den Bossche et al. (2003) and Gijbels, Dochy, van den Bossche et al. (2005) show effects in favour of PBL: for the organization of the knowledge structure $(\mathrm{ES}=0,339)$, for concepts and principles of conditions and procedures (ES $=0.795)$ (Gijbels et al., 2005, p. 31). The overall meta-synthesis of Strobel and van Barneveld (2009) demonstrates an advantage for PBL with regard to performance or skill based assessment and mixed-knowledge and skills whereas pure knowledge assessment shows an advantage of traditional learning. This is in correspondence with the critique of Kirschner, Sweller and Clark (2006) who emphasize the importance of systematic support of learning processes. This is one reason that we linked the PBL with phases of professional coaching (see especially, Seidel \& Shavelson, 2007; Mayer, 2008, pp. 277-284). The meta-analysis of Fraser et al. (1987) showed an effect size of .50 for support by student tutors and an effect size of .65 for informative feedback (cited in Frey \& Frey-Eiling, 1993, chap. 1, pp. $9,12)$.

(C) To support the development of domain-specific knowledge (systematic knowledge on business but also on teamwork etc.) the students have to attend lectures which present the necessary knowledge and information. Within our course we focus on the first phase of entrepreneurial activities, especially on the creation and writing of a business plan for a real entrepreneur: Thus, the content of the lectures is related to «product and service» (Module I), «market and competition» (Module II), «sales and marketing» (Module III), «business model and organization» (Module IV) as well as «financial plan» (Module V) focusing on hard and soft skills (cf. Arndt, 2006; evobis, 2011). Therefore, we explicitly link theory and practice in a structured way by inviting real entrepreneurs into the lectures underlining and visualizing the academic content by introducing related soft skills to authentic examples. By this treatment we try to connect «casuistic and systematic» experiences and reflections (Achtenhagen, in this volume; Reetz \& Tramm, 2000). The effectiveness of systematically structured inputs by lectures and straight teaching is shown within several studies (cf. Brophy \& Good, 2000; Walberg \& Paik, 2000; Seidel \& Shavelson, 2007). The meta-analysis of Fraser et al. (1987) showed an effect size of .55 for explicit and direct teaching (cited in Frey \& Frey-Eiling, 1993, chap. 1, p. 12).

(D) These lectures are linked to corresponding tutorials providing the learners the chance to work in small groups, to focus attention on special issues of the group work, to repeat and exercise selected issues, to link existing and new knowledge, to deepen understanding, to rise cognitive flexibility, to probe understanding, and to get individual feedback (e.g. Hasselhorn \& Gold, 2006, pp. 54-56). By this treatment we try to develop mental models according to the course goals on business issues but also on team skills like e.g. supportive communication styles, meaning and impact of discussion rules, planning procedures and also to provide individual time for learning and the opportunity to probe these soft-skills like information search, pre- 
senting and teamwork etc. Probing has still its effects (cf. Mayer, 2008, pp. 285291). The meta-analysis of Fraser et al. (1987) showed an effect size of .78 for such tutorials (cited in Frey \& Frey-Eiling, 1993, chap. 1, p. 15; see also Walberg \& Paik, 2000).

(E) To support individual learning by this open learning environment we offer additional e-learning modules. Main intention is to pinpoint selected skills, especially, soft-skills as decisive skills for creating a business plan (teamwork, presenting, argumentation). Therefore, we created a pool of domain-specific e-learning tasks (especially for fostering teamwork skills) using the «four component instructional design» (4C/ID) approach of van Merriënboer \& Kirschner (2007). It is supported by research results of a meta-analysis of Marzano et al. (2001, p. 32; see also Merrill, Barclay \& van Schaak, 2008). Here, we concentrate according to our empirical studies on most relevant and critical situations in teamwork (Table 1). On the basis of our operationalization of team competencies (Figure 1) as well as of literature of best practice we created a skill hierarchy for these performance goals and built two task classes which differ as the complexity and difficulty increase from task class one to task class two (e.g. working in a homogeneous team in task class one and then approaching to heterogeneous teams in task class two). Within each of the task classes we built three tasks of the same achievement level but with different degrees of built-in support (e.g. they start with a «worked-out example» [Mayer, 2008, pp. 329-349] getting guidance to recognize different categories and problems of teamwork; in the second task the students have to complete a team moderating process by writing a protocol [《completion task»] supported by the possibility to download alternative blue-prints from the e-learning platform, and in the third task they have to moderate their real team without any support [«conventional task»]). By this scaffolding and fading procedure the students get additional supportive information gained from science and practice on the topic for non-concurrent actions/ aspects to build and develop their mental model and to link their skills to a conceptual framework. They also receive procedural information on algorithms and rules of thumb for concurrent actions just in time while probing and practicing performance. During the whole learning process the learners get feedback (automatized and faceto-face). Tasks, cases, information, scripted protocols are given by multimedia products (podcasts, video clips, video tutorials, recorded interviews, documents, scripted protocols, forms, excerpts of text books etc.). By this e-learning platform/treatment we are able to guide learning progression and working processes with regard to knowledge and skills by scripted protocols (e.g. on information search, managing team processes (communication, monitoring), presenting strategies etc., checking knowledge and understanding by multiple-choice tasks, giving quick and similar feedback by automatization, providing all information for all participants from the very beginning (e.g. Ertl \& Mandl, 2004, on scripted cooperation; Mayer, 2008, pp. 321-325, computers enabling meaningful methods of instruction for teaching transferable problem-solving skills; Van Merriënboer \& Kirschner, 2007). Hereby, the students acquire conceptual knowledge, measures, techniques, strategies which en- 
able them to master the complex situational affordances alone and also beyond the classroom (Hager \& Hasselhorn, 2000, p. 42). A large meta-analysis of the US Department of Education (2010) showed that computer-supported learning has only moderate effects compared to normal classroom learning (a comparable value, ES = 0.31 is given by Fraser et al., 1987; cited in Frey \& Frey-Eiling, 1993, chap. 1, p. 15). The effects are higher if the studies follow a blended-learning approach (US Department of Education, 2010, p. 51).

(F) The course ends with a team presentation of its work (business plan) in front of an expert jury (teaching assistant, student tutor, entrepreneur) and gets evaluated and graded. Additionally, there is a closing ceremony where keynote speakers from sciences and business practice again underline the importance of entrepreneurial activities from a political, economic or personal perspective and encourage the students by exceptional examples. Furthermore, the best teams get awarded for their business plans (see the importance of reward structures according to the model of effective team learning: Tannenbaum et al., 1992). By this treatment we try to uphold the entrepreneurial spirit, keep role models aware, honor exceptional student teamwork as well as how the students have contributed through their intensive teamwork to an individual real life project. This shall evoke the students to reflect on their own and team-related feasibility (e.g. what domain-specific knowledge and skills they have learned: e.g., with which results they actually come up, results with which no one would have come up alone but only by a team), reflect on the attractiveness of start-ups, stimulating their career decisions on entrepreneurial intentions, as well as on how particular social needs can be solved by innovative and creative business ideas, such like social entrepreneurship (Mayer, 2008, pp 273-277).

\section{Does the «instruction»/intervention matter?}

The aim was to suggest and to implement a research- and evidence-based entrepreneurship course on the basis of the «curriculum-instruction-assessment triad» focusing on the instruction component - here restricted to team competencies. The intention was to foster and develop domain-specific knowledge, skills and attitudes for mastering team situations within entrepreneurial (business planning) courses (Figure 1). Making the linkage to the assessment component of the triad the intervention is evaluated by three research questions (Hager, Patry \& Brezing, 2000). These are:

- Do the students perceive and pick up our instructional offer?

- Do the students perceive and pick up our instructional offer in the same way?

- Do the students' team competencies increase over time?

The whole cohort of 430 bachelor students of business administration in the winter semester 2010/11 was involved in the sample. The control group consisted of the whole cohort of students in human resource education and management ( 68 bachelor students, 90 diploma students). We collected the data via paper-and-pencil at the 
beginning of the course (t1) and via online-questionnaire at the end of the course (t2). The course lasts a whole semester. The students had an average age of 22 years (18 years min.; 33 years max.); 63,4\% of the complete data set were female; 19,5\% had successfully completed an apprenticeship; $61,9 \%$ had a current study grade of 2,49 and better $(1=$ best grade; $6=$ worst grade). The response rate was $88 \%$ in $\mathrm{t} 1$ and $82 \%$ in $\mathrm{t} 2 .^{2}$

For answering our first research question we run a simple descriptive design where we describe the distribution for the crucial constructs of efficient teamwork identified by Tannenbaum et al. (1992). For answering the second research question we run a comparative design to figure out whether different groups of the cohort (e.g. gender, prior achievement, completed apprenticeship) perceive our instructional offer in a different way. For answering the third question we run a pre-post-experimental control group design by which we monitored the change with regard to team knowledge, skills and attitudes as central resources of team competence.

We used the following instruments to get information about the critical factors of team learning according to Tannenbaum et al. (1992): INPUT: (1) task characteristics (Cronbach's alpha: 0,533): self-constructed items according to Noß (2000: e.g. «The task was difficult to solve», «Without my team I never would have mastered this task»); PROCESS: (2) team interaction (Cronbach's alpha: 0,886): self-constructed items according to Kauffeld (2004); Brodbeck, Anderson \& West (2000); Campion, Medsker \& Higgs (1993); INTERVENTION: (3) intervention conditions (Cronbach's alpha: 0,659): 6 items of Prenzel \& Drechsel (1996); (4) e-learning (Cronbach's alpha: 0,721): adapted scale of HILVE of Rindermann \& Amelang (1994; added with own items); FEEDBACK: (5) feedback (Cronbach's alpha: 0,711): 3 items of Prenzel \& Drechsel (1996); OUTPUT: (6) satisfaction with the team result (Cronbach's alpha: 0,864): subscale of the BEvaKomp (Braun et al., 2008); (7) intention to work in a team (Cronbach's alpha: 0,935): self-constructed items in analogy to Liñán \& Chen (2009). As instruments for monitoring and measuring central dispositions of team competencies we used (8) three one-item-scales for team knowledge, team skills and team attitudes (self-constructed); (9) the subscale of the BEvaKomp of Braun et al. (2008) focusing on team skills; (10) the scale of the ALL-Study (Baker et al., 2005) measuring team attitudes and the teamwork KSA of Stevens and Campion (1999) with 35 items (see Table 2). Additionally we collected some biographical data.

Whereas all questionnaires used a Likert-scale (ranging from 1, low agreement, to 7, high agreement) the teamwork KSA is a situational judgment test visualizing cognitive achievement. It is based on one correct answer out of four alternatives. One example is given in Figure 3 below.

2 As for the whole study research questions are raised for all three evaluation steps we implied and collected data within a pre-post-experimental control group design. These data, analyses and results going beyond the sample means will be reported by Funke (forthcoming). 
Figure 3: Example of one KSA item

Suppose that you find yourself in an argument with several co-workers about who should do a very disagreeable, but routine task. Which of the following would likely be the most effective way to resolve this situation?

A: Have your supervisor decide, because this would avoid any personal bias.

$\mathrm{B}$ : Arrange for a rotating schedule so everyone shares the chore.

C: Let the workers who show up earliest choose on a first come, first served basis.

D: Randomly assign a person to do the task and don't change it.

Source: Stevens \& Campion, 1999, pp. 225-226

By the analyses we got the following results:

With regard to research question (1) we monitored central constructs of our researchbased teaching-learning environment. The analyses came to the following results as shown in Table 2. We interpret these results as follows: Nearly all means lie above the theoretical scale mean. The task of creating the business plan for a real entrepreneur is perceived as challenging on a medium level of difficulty. Students enter with low experience of teamwork, with medium level of prior knowledge and skills and have a high attitude to learn more about teamwork; students are interested in the course, students' teamwork processes are intensive, the learning conditions of the intervention are perceived as positive with regard to the atmosphere, acceptance and possibility to overtake responsibility. The e-learning offer is highly appreciated. Coaches give an informative feedback. Students are satisfied and intend to engage into more teamwork in the future. That means our complex, interactive and authentic teaching-learning environment START with its real life tasks evokes goal-oriented team behavior and offers learning opportunities for developing team competencies.

Table 2: Descriptive overview on selected critical constructs of the teaching-learning environment

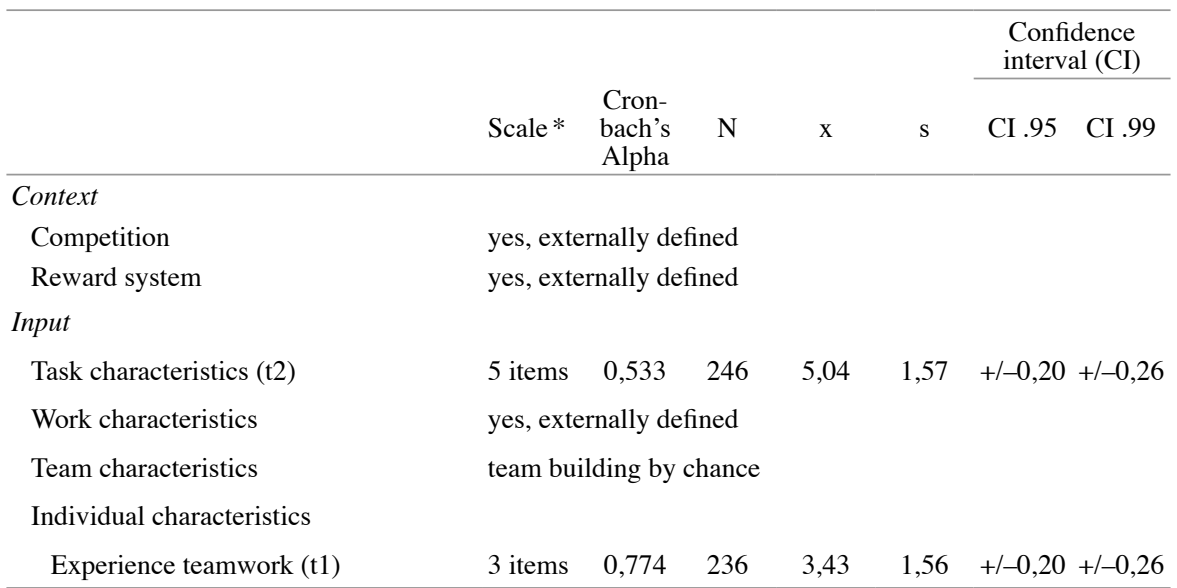




\begin{tabular}{|c|c|c|c|c|c|c|c|}
\hline & Scale* & C. $\alpha$ & $\mathrm{N}$ & $\mathrm{x}$ & $\mathrm{s}$ & CI .95 & CI .99 \\
\hline Knowledge teamwork (t1) & 1 item & & 245 & 4,93 & 1,00 & $+/-0,13$ & $+/-0,17$ \\
\hline Skills teamwork (t1) & 1 item & & 245 & 5,34 & 0,91 & $+/-0,11$ & $+/-0,15$ \\
\hline Attitudes teamwork (t1) & 1 item & & 245 & 5,34 & 1,14 & $+/-0,14$ & $+/-0,15$ \\
\hline Team competencies (skills; BVK) (t1) & 5 items & 0,912 & 232 & 4,95 & 1,48 & $+/-0,19$ & $+/-0,25$ \\
\hline Attitudes teamwork (ALL) (t1) & 15 items & 0,824 & 242 & 4,74 & 1,29 & $+/-0,16$ & $+/-0,21$ \\
\hline Team competencies $(\mathrm{KSA})(\mathrm{t} 1)$ & 35 items & 0,560 & 246 & 18,67 & 4,23 & $+/-0,52$ & $+/-0,84$ \\
\hline Attractiveness for start-up (t1) & 5 items & 0,919 & 243 & 4,53 & 1,56 & $+/-0,20$ & $+1-0,26$ \\
\hline Feasability for start-up (t1) & 6 items & 0,883 & 241 & 3,71 & 1,73 & $+/-0,22$ & $+1-0,29$ \\
\hline Intention for start-up (t1) & 5 items & 0,952 & 243 & 3,62 & 1,69 & $+/-0,21$ & $+1-0,30$ \\
\hline Motivation for learning (t1) & 12 items & 0,579 & 235 & 3,88 & 1,31 & $+/-0,17$ & $+/-0,22$ \\
\hline $\begin{array}{l}\text { Motivation for learning }(\mathrm{t} 1) \\
\text { (without a motivation and extrinsicly motivated) }\end{array}$ & 8 items & 0,791 & 237 & 4,76 & 1,35 & $+/-0,17$ & $+/-0,23$ \\
\hline \multicolumn{8}{|l|}{ Team process } \\
\hline Team interactions ( $\mathrm{t} 2$ ) & 10 items & 0,886 & 246 & 5,40 & 1,50 & $+/-0,19$ & $+/-0,25$ \\
\hline \multicolumn{8}{|l|}{ Team interventions } \\
\hline Intervention frame conditions ( $\mathrm{t} 2$ ) & 6 items & 0,659 & 246 & 4,90 & 1,34 & $+/-0,17$ & $+1-0,22$ \\
\hline E-learning (t2) & 8 items & 0,721 & 229 & 4,14 & 1,49 & $+/-0,19$ & $+1-0,25$ \\
\hline \multicolumn{8}{|l|}{ Feedback } \\
\hline Coaching team (t2) & 3 items & 0,711 & 246 & 4,48 & 1,66 & $+/-0,21$ & $+1-0,27$ \\
\hline \multicolumn{8}{|l|}{ Output } \\
\hline Satisfied with the team result ( $\mathrm{t} 2)$ & 3 items & 0,864 & 246 & 5,30 & 1,60 & $+/-0,20$ & $+1-0,26$ \\
\hline Intention to work in a team (t2) & 4 items & 0,935 & 246 & 5,00 & 1,53 & $+/-0,19$ & $+/-0,25$ \\
\hline
\end{tabular}

Source: own data

With regard to our research question (2) we implied a comparative analysis. Here we tried to prove if all students picked up our treatment in the same way or if specific subgroups are preferred. For controlling these questions we analyzed the perceptions for the following subgroups: gender, average degree of current study achievement (low vs. high achievers) and completed vocational apprenticeship with regard to task characteristics, team process, team intervention conditions and feedback. We found only two significant differences: high achievers perceive the task characteristics more challenging than low achievers ${ }^{3}:\left(n_{\text {high achiever }}=146, x=5,19, \mathrm{~s}=0,866\right.$ vs. $n_{\text {low }}$ achiever $=90, \mathrm{x}=4,87, \mathrm{~s}=0,991): \mathrm{t}=2,668 ; \mathrm{df}=234, \mathrm{p}=0,011$, Eta $=0,027$. Students with a completed apprenticeship perceived the task characteristics less challenging than students without such an apprenticeship: $\left(\mathrm{n}_{\text {with apprenticeship }}=48, \mathrm{x}=4,77\right.$,

3 Grades on the average degree of current study achievement $<2,5$ are categorized as high; grades $>=$ 2,5 as low). 
$\mathrm{s}=0,946$ vs. $\left.\mathrm{n}_{\text {no apprenticeship }}=198, \mathrm{x}=5,11, \mathrm{~s}=0,917\right): \mathrm{t}=2,252 ; \mathrm{df}=244, \mathrm{p}=0,025$, Eta $=0,020 .^{4}$

With regard to research question (3) we can state by a very first access to our analyses that the central resources of team competencies increased for the experimental group (Table 3a): whereas the facets of team competencies like knowledge and skills changed significantly, the team related attitudes stayed the same.

Table 3a: Change of team knowledge, skills and attitudes - experimental group

\begin{tabular}{lccccccc}
\hline Experimental group & $\mathrm{x} \mathrm{t1}$ & $\mathrm{s} \mathrm{t1}$ & $\mathrm{x} \mathrm{t2}$ & $\mathrm{s} \mathrm{t2}$ & $\mathrm{N}$ & $\mathrm{p}$ & $\mathrm{D}$ \\
\hline Teamwork KSA & & & & & & & \\
Total scale & 18.67 & 4.23 & 21.17 & 4.22 & 246 & .000 & .59 \\
Relation management & 12.51 & 3.12 & 14.03 & 3.09 & 246 & .000 & .49 \\
Task management & 6.15 & 1.86 & 7.14 & 1.81 & 246 & .000 & .63 \\
Teamwork skills & & & & & & & \\
BEvaKomp team & 4.92 & 1.30 & 5.98 & .93 & 238 & .000 & .95 \\
Team attitudes & & & & & & & \\
Total scale & 4.75 & .70 & 4.71 & .89 & 245 & .342 & - \\
\hline
\end{tabular}

Source: own data

The analyses for the control group (Table 3b) showed that they started on a comparable level of team competencies. The facets of knowledge and skills for teamwork also increased for the control group but not always in a significant way. Significant changes occur with regard to the subscale of task management and the facet of skills (measured by the BEvaKomp self-report). The facet of attitudes remains also on the same level.

Table 3b: Change of team knowledge, skills and attitudes - control group

\begin{tabular}{lccccccc}
\hline Control group & x t1 & s t1 & x t2 & s t2 & N & p & D \\
\hline Teamwork KSA & & & & & & & \\
Total scale & 18.59 & 4.28 & 20.91 & 3.44 & 22 & .066 & - \\
Relation management & 13.05 & 2.52 & 14.05 & 3.12 & 22 & .246 & - \\
Task management & 5.55 & 2.32 & 6.86 & 1.46 & 22 & .043 & .69 \\
Teamwork skills & & & & & & & \\
BEvaKomp team & 4.57 & 2.09 & 6.26 & .69 & 18 & .002 & 1.22 \\
Team attitudes & & & & & & & \\
Total scale & 4.80 & .94 & 4.85 & .81 & 22 & .674 & - \\
\hline
\end{tabular}

Source: own data

4 Effect size for t-test for paired samples has been calculated using the following formula: $d=(x t 2-x t 1)$ $/((\mathrm{st} 1+\mathrm{st} 2) / 2)(\mathrm{cf}$. Brace, Kemp \& Snelgar, 2006, p. 82); for reference: $\mathrm{d}=0,2$ (small), $\mathrm{d}=0,5$ (medium), d = 0, 8 (large) (Weinberg \& Abramowitz, 2002, p. 263). 
Our interpretation is that we succeeded with our instruction in changing facets of team competencies as knowledge and skills in the intended direction. It is not astonishing that the attitudes stayed the same as they have to be seen as a more enduring construct which cannot be developed in such a short time as one semester. The control group develops also in the positive direction although they did not get an explicit treatment and support in teamwork. This might be explained by the fact that this group also worked within the traditional teaching format at university in lectures, tutorials and (unsystematically) in small groups, but did not get any team supporting instruction, material etc. Thus, especially task management might improve for the control group by «muddling through».

\section{Summary and discussion}

The aim was to overcome the highly fragmented and isolated and often naïvely composed didactical components in entrepreneurship courses by using the heuristic frame of the curriculum-instruction-assessment triad (Pellegrino, 2010). We, therefore, identified on the basis of an extended literature research precise curricular goals for our entrepreneurship course of bachelor students. On the basis of several metaanalyses, narrative reviews on teaching-learning as well as on curricular approaches - which give hints of the nature of knowledge, skills and attitudes and how they can be taught (Schiro, 2008) - we selected instructional components and justified them with regard to our defined learning goals of developing team knowledge, team skills and team attitudes. Although we have not analyzed all data yet our descriptive assessment shows that the students picked-up our research- and evidence-based teaching-learning environment. The task to be solved by the teams was of high interest and challenging on a medium level of aspiration which is good for starting learning processes (Weiner, 1986). With regard to prior experiences of teamwork the students start in the average on a relatively low level so that they have room for development - a result that legitimized our decision of focusing on team competencies as a key competence in this bachelor program. The students perceived supportive learning conditions as e-learning and feedback. They engaged very intensively into team interactions and were satisfied with their team results. They also stick with their positive attitude for teamwork and stated their intention to work also in the future in teams. As this output variable is formulated analogously to Ajzen's model of planned behavior, we can expect that the students really will do this.

From our subgroup comparison we can conclude that students with an apprenticeship might have better abilities in organizing work processes and have according to their experiences in real working life adequate estimations and judgments on task affordances and how to cope with them efficiently and effectively; that means, they know which tasks are better done alone and which are better done in a team so that they perceive the team tasks less challenging. 
With regard to the pre-post-experimental control group design we could state a development of team competencies and an increase of the students' team knowledge and team skills for the experimental group.

By these results - showing especially the degree to which the treatment is implemented as planned - we will have a sound basis for further analyses of the impacts of the treatment as well as reasons for special effects (cf. Hager et al., 2000) which will be reported subsequently.

\section{Limitations and further research}

For meeting the whole quality criteria of intervention evaluations according to Patry and Perrez (2000) we still have to extend and to deepen our analyses on the three evaluation steps - especially with regard to validation issues. Although we constructed our instruction on the basis of current national and international scientific knowledge and research results, explained why we selected each component and estimated the probability of success for this course we cannot relate each single instruction component to a single effect; furthermore we have to extend the control group to strengthen causality. Considering the costs and benefits ratio we can state that this course is a huge effort, but with regard to our first monitoring results and additional positive side effects (e.g. the students use their learned team behavior also in other courses) $)^{5}$ seem to justify this effort (Patry \& Perrez, 2000, p. 38). With regard to the methodological view we will modify the scales to increase the reliability (especially for task characteristics, KSA). As some of our measures are still based on self-reports we intent do use more cognitive achievement tests by using formats like the KSA of Stevens \& Campion to limit social desirability. For the future we will therefore continue the track on modeling and measuring these competencies more in accordance to formats of e.g. Collegiate Learning Assessment (CLA) (Shavelson, 2010) or open formats as we run for modeling and measuring intercultural competence (Weber, in press). Although our analyses are based on a complete inventory count we have to replicate our instruction and measurement with other cohorts.

\section{References}

Achleitner, K.-A.; Klandt, H.; Koch, L. et al. (2006), Jahrbuch Entrepreneurship 2005/06. Gründungsforschung und Gründungsmanagement. Berlin: Springer

Achtenhagen, F. \& Pätzold, G. (2011). Lehr-Lern-Forschung und Mikrodidaktik. In: R. Nickolaus, G. Pätzold, H. Reinisch et al. (Hrsg.): Handbuch Berufs- und Wirtschaftspädagogik. Bad Heilbrunn: Klinkhardt

Achtenhagen, F. \& Winther, E. (2009). Konstruktvalidität von Simulationsaufgaben: Computergestützte Messung berufsfachlicher Kompetenz - Am Beispiel der Ausbildung von Industriekaufleuten. Abschlussbericht für das BMBF. Göttingen: Professur für Wirtschaftspädagogik der Georg-AugustUniversität

5 Up to now we did not monitor these additional side effects systematically, but they get reported by colleagues and teaching assistants within the faculty. 
Ajzen, I. (1987). Attitudes, Traits, and Actions: Dispositional Prediction of Behavior in Personality and Social Psychology. In: L. Berkowitz (Ed.): Advances in Experimental Social Psychology. New York: Academic Press

Ajzen, I. (1991). The Theory of Planned Behavior. Organizational Behavior and Human Decision Processes, 50(2), 179-211

Anderson, L. \& Krathwohl, D. (2001). A Taxonomy for Learning, Teaching and Assessing. New York: Longman

Armitage, C. J. \& Conner, M. (2001). Efficacy of the Theory of Planned Behaviour: A Meta-Analytic Review. British Journal of Social Psychology, 40(4), 471-499

Arndt, W. (2006). Der optimale Businessplan. Handbuch: Münchner Business-Plan-Wettbewerb. München: panta rhei cm

Ausubel, D. P. (1960). The use of advance organizers in the learning and retention of meaningful verbal material. Journal of Educational Psychology, 51, 267-272

Baker, D. P.; Horvath, L.; Campion, M. et al. (2005). The ALL Teamwork Framework. In: T. S. Murray, Y. Clermont \& M. Binkley (Eds.), International Adult Literacy Survey. Measuring Adult Literacy and Life Skills: New Frameworks for Assessment. Ottawa: Minister of Industry

Ballstaedt, S.-P. (1982). Dokumentenanalyse. In: G. L. Huber \& H. Mandl (Hrsg.): Verbale Daten. Weinheim: Beltz

Braun, E.; Gusy, B.; Leidner, B. et al. (2008). Das Berliner Evaluationsinstrument für selbsteingeschätzte studentische Kompetenzen (BEvaKomp). Diagnostica, 54, 30-42

Bransford, J. D.; Brown, A. L. \& Cocking, R. R. (Eds.) (2000): How People Learn. Brain, Mind, Experience and School. Washington DC: National Academy Press

Briedis, K. (2007). Übergänge und Erfahrungen nach dem Hochschulabschluss. Ergebnisse der HISAbsolventenbefragung des Jahrgangs 2005. www.his.de/pdf/pub_fh/fh-200713.pdf

Brodbeck, F.; Anderson, N. \& West, M. (2000) TKI. Teamklima-Inventar. Göttingen: Hogrefe

Brophy, J. E. \& Good, T. L. (2000). School Effects. In: M. C. Wittrock (Ed.), Handbook of Research on Teaching, 3rd ed. New York: McMillan

Brüderl, J.; Preisendörfer, P. \& Ziegler, R. (2009). Der Erfolg neugegründeter Betriebe. Berlin: Duncker \& Humblot

BMWI [Bundesministerium für Wirtschaft und Technologie] (2006). EXIST. Existenzgründungen aus Hochschulen. Bericht der wissenschaftlichen Begleitung zum Förderzeitraum 1998-2005 (Kurzfsg.) [Forschungsbericht 555] www.exist.de/imperia/md/content/pdf_sonstiges/forschungsbericht_555.pdf

Cannon-Bowers, J. A.; Tannenbaum, S. I.; Salas, E. et al. (1995). Defining competencies and establishing team training requirements. In: R. A. Guzzo, E. Salas, \& I. L. Goldstein (Eds.), Team effectiveness and decision making in organizations. San Francisco: Jossey-Bass

Campion, M. A.; Medsker, G. J. \& Higgs, A. C. (1993). Relations between work group characteristics and effectiveness. Implications for designing effective work groups. Personnel Psychology, 46, 823-850

CTGV [Cognition and Technology Group at Vanderbilt] (1997). The Jasper Project: Lessons in curriculum, instruction, assessment, and professional development. Mahwah NJ: Erlbaum

De Carolis, D. M.; Litzky, B. E. \& Eddleston, K. A. (2009). Why Networks Enhance the Progress of New Venture Creation: The Influence of Social Capital and Cognition. Entrepreneurship Theory and Practice, 33, 527-545

Decuyper, S.; Dochy, F. \& Van den Bossche, P. (2010). Grasping the dynamic complexity of team learning: An integrative model for effective team learning in organisations. Educational Research Review, $5,111-133$

Dochy, F.; Segers, M.; Van den Bossche, P. et al. (2003). Effects of problem-based learning: A metaanalysis. Learning and Instruction, 13, 533-568

Duek, J. L. E. (2000). Whose group is it, anyway? Equity of student discourse in problem-based learning (PBL). In: D. H. Evensen \& C. E. Hmelo (Eds.): Problem-Based Learning - A Research Perspective on Learning Interactions. Mahwah NJ: Erlbaum

Egeln, J.; Dinges, M.; Knie, A. et al. (2010), Evaluation des Existenzgründungsprogramms EXIST III, ZEW Wirtschaftsanalysen, Bd. 95, Baden-Baden: Nomos

Engle, R. L., Dimitriadi, N., Gavidia, J. V. et al. (2010). Entrepreneurial Intent - a Twelve-Country Evaluation of Ajzen's Model of Planned Behavior. International Journal of Entrepreneurial Behaviour \& Research, 16 (1), 35-57 
Ertl, B. \& Mandl, H. (2004). Kooperationsskripts als Lernstrategie. Forschungsberichte des Instituts für Pädagogische Psychologie, 172. München: LMU

evobis (2011). Handbuch zur Businessplan-Erstellung. www.evobis.de/fileadmin/user_upload/content/ Handbuch/evobis-BP-Handbuch-Web.pdf

Fayolle, A. (2008). Entrepreneurship Education at a Crossroads: Towards a More Mature Teaching Field. Journal of Enterprising Culture, 16(4), 325-337

Fayolle, A. \& Gailly, B. (2009). Assessing the Impact of Entrepreneurship Education: A Methodology and Three Experiments from French Engineering Schools. In: G. P. West, E. J. Gatewood \& K. G. Shaver (Eds.): Handbook of University-wide Entrepreneurship Education. Cheltenham: Elgar

Figl, K. (2010a). A Systematic Review of Developing Team Competencies in Information Systems Education. Journal of Information Systems Education, 21(3), 323-337

Figl, K. (2010b). Team and media competencies in information systems (2nd ed.). München: Oldenbourg

Fraser, B. J.; Walberg, H. J.; Welch, W. W. et al. (1987). Syntheses of Educational Productivity Research. International Journal of Educational Research, 11, 145-252

Frey, K. \& Frey-Eiling, A. (1993). Allgemeine Didaktik. 6. Aufl. Zürich: VDF

Fueglistaller, U.; Klandt, H.; Halter, F. et al. (2009). An International Comparison of Entrepreneurship among Students. St. Gallen: Swiss Research Institute of Small Business and Entrepreneurship

Funke, S. (forthcoming). Modelling and Measuring Team Competencies. München: Ludwig-MaximiliansUniversität München

Gijbels, D.; Dochy, F.; Van den Bossche, P. et al. (2005). Effects of Problem-based Learning: A MetaAnalysis from the Angle of Assessment. Review of Educational Research, 75, 27-61

Glass, G. V.; McGaw, B. \& Smith, M. L. (1991). Meta-Analysis in Social Research. Beverly Hills: Sage

Hager, W., Patry, J. L. \& Brezing, H. (Hrsg.) (2000). Evaluation Psychologischer Interventionsmaßnahmen. Bern: Huber

Hager, W. \& Hasselhorn, M. (2000). Einige Gütekriterien für Kriteriumsmaße bei der Evaluation von Interventionsprogrammen. In: W. Hager, J. L. Patry \& H. Brezing (Hrsg.), Evaluation Psychologischer InterventionsmaßnahmenBern: Huber

Hasselhorn, M. \& Gold, A. (2009). Pädagogische Psychologie. Erfolgreiches Lernen und Lehren (2. Aufl.). Stuttgart: Kohlhammer

Henry, C.; Hill, F. \& Leitch, C. (2003). Entrepreneurship Education and Training. Aldershot: Ashgate

Hmelo, C. E. (1998). Problem-based learning: Effects on the early acquisition of cognitive skills in medicine. The Journal of the Learning Sciences, 7, 173-208

Hmelo-Silver, C. E. (2004). Problem-Based Learning: What and How Do Students Learn? Educational Psychology Review, 16, 235-266

Hmelo, C. E.; Gotterer, G. S. \& Bransford, J. D. (1997). A theory-driven approach to assessing the cognitive effects of PBL. Instructional Science, 25, 387-408

Izquierdo, E. \& Deschoolmeester, D. (2010). What Entrepreneurial Competencies Should be Emphasized in Entrepreneurship and Innovation Education at the Undergraduate Level? In: A. Fayolle (Ed.): Handbook of Research in Entrepreneurship Education, Vol. 3. Cheltenam: Elgar

Kailer, N. (2007). Evaluation of Entrepreneurship Education. In: A. Fayolle (Ed.): Handbook of Research in Entrepreneurship Education: Vol. 2. Cheltenam: Elgar

Kauffeld, S. (2004). Fragebogen zur Arbeit im Team. FAT Manual. Göttingen: Hogrefe

Kirschner, P. A.; Sweller, J. \& Clark, R. E. (2006). Why minimal guidance during instruction does not work: An analysis of the failure of constructivist, discovery, problem-based, experiential, and inquiry-based teaching. Educational Psychologist, 41, 75-86

Klandt, H. (2004a). Unternehmenslebensphasen und ihre erfolgreiche Gestaltung. In: C. Steinle \& K. Schumann (Hrsg.), Gründung von Technologieunternehmen. Wiesbaden: Gabler

Klandt, H. (2004b). Entrepreneurship Education and Research in German-Speaking Europe. Academy of Management Learning \& Education, 3(3), 293-301

Klandt, H. (2006). Gründungsmanagement: Der integrierte Unternehmensplan (2., überarb. Aufl.). München: Oldenbourg

Klieme, E. \& Hartig, J. (2008). Kompetenzkonzepte in den Sozialwissenschaften und im erziehungswissenschaftlichen Diskurs. In: M. Prenzel, I. Gogolin, \& H.-H. Krüger (Hrsg.): Kompetenzdiagnostik. Wiesbaden: VS Verlag für Sozialwissenschaften 
Koch, L. T. (2003). Unternehmerausbildung an Hochschulen. Zeitschrift für Betriebswirtschaft, EH 2, 25-46

Kolvereid, L. \& Isaksen, E. (2006). New Business Start-up and Subsequent Entry into Self-Employment. Journal of Business Venturing, 21(6), 866-885

Kulicke, M. (2006). EXIST - Existenzgründungen aus Hochschulen: Bericht der wissenschaftlichen Begleitung zum Förderzeitraum 1998 bis 2005. Berlin: BWI

Kuratko, D. F. (2005). The Emergence of Entrepreneurship Education: Development, Trends, and Challenges. Entrepreneurship Theory and Practice, 29(5), 577-598

Lang-von Wins, T.; Leiner, R.; von Rosenstiel, L. et al. (2002). Aufgaben und ihre Bewältigung in der Vorgründungs-, Gründungs- und Nachgründungsphase: Eine empirische Erfassung des Verlaufes von geförderten Unternehmensgründungen. In: J. Schmude \& R. Leiner (Hrsg.): Unternehmensgründungen - Interdisziplinäre Beiträge zum Entrepreneurship Research. Heidelberg: Physica

Lee, L.; Wong, P. K.; Foo, M. D. et al.. (2011). Entrepreneurial Intentions: The Influence of Organizational and Individual Factors. Journal of Business Venturing, 26(1), 124-136

Lehmann, R. \& Seeber, S. (2007). ULME III. Untersuchung von Leistungen, Motivation und Einstellungen der Schülerinnen und Schüler in den Abschlussklassen der Berufsschulen. Hamburg: Behörde für Bildung und Sport der Freien Hansestadt Hamburg

Liñán, F. (2004). Intention-based Models of Entrepreneurship Education. Piccola Impresa = Small Business, 3, 11-35

Liñán, F. (2007). The role of entrepreneurship education in the entrepreneurial process. In: A. Fayolle (Ed.): Handbook of Research in Entrepreneurship Education, Vol. 1. Cheltenham: Elgar

Liñán, F. \& Chen, Y.-W. (2009). Development and Cross-Cultural Application of a Specific Instrument to Measure Entrepreneurial Intentions. Entrepreneurship: Theory and Practice, 33(3), 593-617

Liñán, F.; Moriano, J. A. \& Zarnowska, A. (2008). Stimulating Entrepreneurial Intentions Through Education. In: J. A. Moriano, M. Gorgievski \& M. Lukes (Eds.): Teaching Psychology of Entrepreneurship. Madrid: Universidad Nacional de Educación a Distancia (UNED)

Lüthje, C. \& Franke, N. (2003). The «Making» of an Entrepreneur: Testing a Model of Entrepeneurial Intent among Engineering Students at MIT. $R \& D$ Management, 33, 135-147

Mansio, H. (1997). The Effectiveness of Education in terms of Entrepreneurial Activity in Polytechnics. Helsinki: Helsinki School of Economics and Business Administration

Marzano, R. J. \& Kendall, J. S. (2007). The New Taxonomy of Educational Objectives. 2nd ed. Thousand Oaks CA: Corwin

Marzano, R. J.; Pickering, D. J. \& Pollock, J. E. (2001). Classroom instruction that works: Research based strategy for increasing student achievement. Alexandria VA: Association for Supervision and Curriculum Development

Mathieu, J.; Maynard, M.; Rapp, T. et al. (2008). Team Effectiveness 1997-2007: A Review of Recent Advancements and a Glimpse Into the Future. Journal of Management, 34(3), 410-476

Mayer, R. E. (2008). Learning and Instruction. Upper Saddle River NJ: Pearson

Mayring, P. (2002). Einführung in die qualitative Sozialforschung. Eine Anleitung zu qualitativem Denken (5. Aufl.). Weinheim: Beltz

Merrill, M. D.; Barclay, M. \& Van Schaak, A. (2008). Prescriptive Principles for Instructional Design. In: J. M. Spector, M. D. Merrill, J. J. G. van Merrienboer et al. (Eds.), Handbook of Research on Educational Communications and Technology (3rd ed.). New York: Erlbaum, Taylor \& Francis

Müller, S. (2011). Increasing Entrepreneurial Intention: Effective Entrepreneurship Course Characteristics. International Journal of Entrepreneurship and Small Business, 13(1), 55-74

Nickolaus, R. (2011). Die Erfassung beruflicher Kompetenzen und ihrer Entwicklungen in der beruflichen Bildung - Forschungsstand und Perspektiven. In: O. Zlatkin-Troitschanskaia (Hrsg.), Stationen Empirischer Bildungsforschung. Wiesbaden: VS Verlag für Sozialwissenschaften

Noß, M. (2000). Selbstgesteuertes Lernen am Arbeitsplatz. Wiesbaden: Gabler

Oosterbeek, H., van Praag, M. \& Ijsselstein, A. (2010). The Impact of Entrepreneurship Education on Entrepreneurship Skills and Motivation. European Economic Review, 54(3), 442-454

Patry, J.-L. \& Perrez, M. (2000). Theorie-Praxis-Probleme und die Evaluation von Interventionsprogrammen. In: W. Hager, J.-L. Patry \& H. Brezing (Hrsg.): Evaluation Psychologischer Interventionsmaßnahmen. Bern: Huber 
Pellegrino, J. W. (2010). The Design of an Assessment System for the Race to the Top: A Learning Sciences Perspective on Issues of Growth and Measurement. Princeton: Educational Testing Service

Peterman, N. \& Kennedy, J. (2003). Enterprise education: influencing students' perceptions of entrepreneurship. Entrepreneurship Theory and Practice, 28(2), 129-144

Peterson, N. G.; Mumford, M. D.; Borman, W. C. et al. (2001), Understanding work using the occupational information network (O*NET): Implications for practice and research. Personnel Psychology, $54,451-492$

Peterson, N. G.; Mumford, M. D.; Borman, W. C. et al. (Eds.) (1999). An Occupational Information System for the 21st Century: The Development of O*NET. Washington DC: American Psychological Association

Pittaway, L. \& Cope, J. (2007). Entrepreneurship Education - A Systematic Review of the Evidence. International Small Business Journal, 25(5), 477-506

Prenzel, M. \& Drechsel, B. (1996). Ein Jahr kaufmännische Erstausbildung. Veränderungen in Lernmotivation und Interesse. Unterrichtswissenschaft, 24, 217-234

Reetz, L \& Tramm, T. (2000). Lebenslanges Lernen aus der Sicht einer berufspädagogisch und wirtschafts-pädagogisch akzentuierten Curriculumforschung. In: F. Achtenhagen \& W. Lempert (Hrsg.), Le-benslanges Lernen im Beruf. Seine Grundlegung im Kindes- und Jugendalter. Bd. V. Opladen: Leske + Budrich

Reynolds, P. D. (2007). New Firm Creation in the US: A PSED I Overview. Foundations and Trends in Entrepreneurship, 3(1), 1-149

Rindermann, H. \& Amelang, M. (1994): Das Heidelberger Inventar zur Lehrveranstaltungsevaluation (HILVE): Handanweisung. Heidelberg: Asanger

Schiro, M. S. (2008). Curriculum Theory. Conflicting Visions and Enduring Concerns. Thousand Oaks: Sage

Schmude, J.; Heumann, S. \& Wagner, K. (2009). Ranking 2009: Vom Studenten zum Unternehmer: Welche Universität bietet die besten Chancen? Düsseldorf: Handelsblatt-Verlag

Schumpeter, J. A. (1911). The Theory of Economic Development. Cambridge MA: Harvard University Press

Seeber, S. (2008). Ansätze zur Modellierung beruflicher Fachkompetenz in kaufmännischen Ausbildungsberufen. Zeitschrift für Berufs- und Wirtschaftspädagogik, 104, 74-97

Seeber, S. \& Nickolaus, R. (2010). Kompetenz, Kompetenzmodelle und Kompetenzentwicklung in der beruflichen Bildung. In: R. Nickolaus, G. Pätzold, H. Reinisch et al. (Hrsg.): Handbuch Berufs- und Wirtschaftspädagogik. Bad Heilbrunn: Klinkhardt

Seidel, T. \& Shavelson, R. J. (2007). Teaching Effectiveness Research in the Past Decade: The Role of Theory and Research Design in Disentangling Meta-Analysis Results. Review of Educational Research, 77(4), 454-499

Shavelson, R. J. (2010). Measuring College Learning Responsibly. Accountability in a New Era. Stanford CA: Stanford University Press

Sherman, P.; Sebora, T. \& Digman, L. (2008). Experiential Entrepreneurship in the Classroom: Effects of Teaching Methods on Entrepreneurial Career Choice Intentions. Journal of Entrepreneurship Education, 11, 29-42

Shulman, L. S. (1986). Paradigms and Research Programs in the Study of Teaching: A Contemporary Perspective. In: M. C. Wittrock (Ed.): Handbook of Research on Teaching (3rd ed.). New York: McMillan

Souitaris, V.; Zerbinati, S. \& Al-Laham, A. (2007). Do entrepreneurship programmes raise entrepreneurial intention of science and engineering students? The effect of learning, inspiration and resources. Journal of Business Venturing, 22, 566-591

Starke, S. (2011). Fostering Networking as a Decisive Entrepreneurial Ability. Munich: Dr. Hut

Stevens, M. J. \& Campion, M. A. (1994). The Knowledge, Skill and Ability Requirements for Teamwork: Implications for Human Resource Management. Journal of Management, 20(2), 503-530

Stevens, M. J. \& Campion, M. A. (1999). Staffing Work Teams: Development and Validation of a Selection Test for Teamwork Settings. Journal of Management, 25(2), 207-228

Strobel, J. \& van Barneveld, A. (2009). When is PBL More Effective? A Meta-synthesis of Meta-analyses Comparing PBL to Conventional Classrooms. The Interdisciplinary Journal of Problem-based Learning, 3, 44-57 
Tannenbaum, S. I.; Beard, R. L. \& Salas, E. (1992). Team building and its influence on team effectiveness: An examination of conceptual and empirical developments. In: K. Kelley (Ed.): Issues, Theory and Research in Industrial/Organizational Psychology. Amsterdam: Elsevier

Tkachev, A. \& Kolvereid, L. (1999). Self-employment intentions among Russian students. Entrepreneurship \& Regional Development, 11, 269-280

Uebelacker, S. (2005). Gründungsausbildung. Entrepreneurship Education an deutschen Hochschulen und ihre raumrelevanten Strukturen, Inhalte und Effekte. Wiesbaden: Deutscher Universitäts-Verlag

Unger, J. M.; Rauch, A.; Frese, M. et al. (2011). Human Capital and Entrepreneurial Success: A MetaAnalytical Review. Journal of Business Venturing, 26, 341-358

US Department of Education (2010). Evaluation of Evidence-based Practices in Online Learning: A Meta-Analysis and Review of Online Learning Studies. Washington: US Department of Education

Van Merriënboer, J. J. G. \& Kirschner, P. A. (2007). Ten Steps to Complex Learning. A systematic approach to four-component instructional design. Mahwah: Erlbaum

Volery, T. \& Shaper, M. (2007). Entrepreneurship and Small Business: A Pacific Rim Perspective. Milton QLD: Wiley

Volkmann, C.; Wilson, K.; Mariotti, S. et al. (2009). Educating the Next Wave of Entrepreneurs. Geneva: World Economic Forum

Von Graevenitz, G.; Harhoff, D. \& Weber, R. (2010). The effects of entrepreneurship education. Journal of Economic Behavior and Organization, 76(1), 90-112

Walberg, H. J. \& Paik, S. J. (2000). Effective Educational Practices. Geneva: IBE-UNESCO

Walter, S. G. \& Walter, A. (2008). Deutsche Universitäten als Gründungsinkubatoren: Der Beitrag der Gründungsausbildung zur Gründungsintention von Studierenden. Zeitschrift für betriebswirtschaftliche Forschung, 60, 542-569

Weber, S. (in press). Measuring intercultural competence within vocational education. European Journal of Training and Development

Weber, S. \& Starke, S. (2010). Lernpotenzial und Effekte eines Business-Planning-Kurses. Unterrichtswissenschaft, 38, 292-317

Weber, S. \& Hofmuth, M. (2011): Zur Messung interkultureller Kompetenz. In: U. Faßhauer, J. Aff, B. Fürstenau et al. (Hrsg.): Lehr-Lernforschung und Professionalisierung. Perspektiven der Berufsbildungsforschung. Leverkusen: Budrich

Weber, S. \& Hofmuth, M. (2012). Messung unterschiedlicher Facetten von interkultureller Kompetenz. In: G. Niedermair (Hrsg.): Kompetenzen entwickeln, messen und bewerten. Linz: Trauner

Weinberg, S. L. \& Abramowitz, S. K. (2002). Data Analysis for the Behavioral Sciences Using SPSS. Cambridge: Cambridge University Press

Weiner, B. (1986). An attribution theory of motivation and emotion. New York: Springer

Weinert, F. E. (2002). Vergleichende Leistungsmessung in Schulen - eine umstrittene Selbstverständlichkeit. In: F. E. Weinert (Hrsg.),: Leistungsmessungen in Schulen. (2. Aufl.) Weinheim: Beltz

Wiggins, G. \& McTighe, J. (2005). Understanding by Design. Alexandria VA: ASCD

Wilson, M.; Bejar, I.; Scalise, K. et al. (2010). Draft White Paper 2: Perspectives on methodological issues. Melbourne: ACTS

Winther, E. (2010). Kompetenzmessung in der beruflichen Bildung. Bielefeld: Bertelsmann

Woolfolk, A. (2008). Pädagogische Psychologie.(10. Aufl.) München: Pearson 